\title{
IMPLEMENTASI PERATURAN DAERAH TENTANG PELAYANAN PUBLIK DI KOTA SURABAYA
}

\author{
Windiani
}

\begin{abstract}
This research aim to know about interpretation and implementation low of Public Service in Surabaya. Beside that, to aim for complicated researchs about region law within public service in Surabaya and give in put to decision maker to attitude law of public service in Surabaya. This research do in Surabaya city and take many public officials as informant with snowball sampling model. This is kualitatif research with use diskriptif analysis. Out put of this research show that interpretation of public officials to law of public serveice in Surabaya city is diferents because; First, the law of public service is new, so there is not technical references to interpretation law of public service. Second, every public service have subject service and character diferences so, interpretation of pubic service become different. Third, there is not the

same of reference to implementation of low public services. Fourth, there is not change paradigm of public officials that they should give service not serviced by public. But, in generally, for many official public that's mean as commitment type of government to increase quality of public service espesialy for Surabaya citizen. Althougt, consciously that implementation law of public service not opptimaly because many resion: there are not Standart of minimum Services from public services, quality of human resoursches, and carrying capacity of services not good.
\end{abstract}

Keywords: public service, region law, interpretation, government.

Kebutuhan akan perbaikan pelayanan publik semakin dirasakan akan arti pentingnya. Dengan peningkatan pelayanan public maka akan semakin mempererat antara masyarakat di satu pihak dan aparatur pemerintah di pihak lain. Era reformasi ini bermaksud merubah paradigma birokrasi agar lebih berorientasi pada masyarakat, bukan pada kekuasaan. Aparat pemerintah adalah pengabdi dan pelayan masyarakat, bukan penguasa apalagi pemaksa atas kepentingan-kepentingannya. Sudah bukan rahasia, meskipun tersendat dalam legislasi RUU Pelayanan Publik di tingkat nasional, namun Pemerintah Jawa Timur khususnya melakukan terobosan seiring dengan kewenangan otonomi daerah mengeluarkan Perda No 11 / 2005 tentang Pelayanan Publik. Hal ini 
tentunya memberi harapan besar akan semakin baiknya pelayanan public di Jawa Timur umumnya dan Kota Surabaya pada khususnya.

Belum genap sepuluh hari Perda No 11 / 2005 tentang Pelayanan Publik Jawa Timur disosialisasikan, langsung direspon oleh berbagai kalangan masyarakat. Muncul berbagai pengaduan sebagai contoh Seorang pengusaha melalui Ketua Yayasan Lembaga Perlindungan Konsumen (YLKP) Jawa Timur, M.Said Utomo (Jawa Pos, 27 Desember 2005) mengadukan bahwa pengurusan izin usaha sudah selama 2 tahun tetapi belum lolos juga.

Selain kasus izin kepemilikan, yang paling sering terjadi adalah rumit serta mahalnya biaya kepengurusan identitas diri di Surabaya. Selama Januari sampai Desember 2005 kolom surat pembaca sering dipenuhi keluhan masyarakat kota Surabaya tentang rumitnya kepengurusan di tingkat Kelurahan dan Kecamatan mulai dari Kartu Identitas Diri (KTP), Kartu Keluarga (KK), Surat Kelahiran, Surat Kematian dan lain-lain. Belum lagi lebih mahalnya biaya kepengurusan surat identitas dibanding harga resminya serta tidak adanya tanda bukti pembayaran (kuitansi) dari instansi pemerintah tersebut. Sekali lagi munculnya kendala Pelayanan Publik di tingkat Kelurahan / Kecamatan dengan peristiwaperistiwa di atas.

Keluhan tentang pelayanan publik di Dinas Catatan Sipil Pemkot Surabaya marak di kolom pembaca Jawa Pos selama Januari - Februari 2006. Ini berarti sudah sebulan Perda Pelayanan Publik diterapkan namun ternyata pelayanan publik belum dilaksanakan dengan sepenuh hati. Salah satu keluhan di Dinas Catatan Sipil adalah masalah penulisan nama pada pengurusan akte lahir bagi Warga Negara Asing (WNA) yang telah menjadi Warga Negara Indonesia (WNI). Mereka diwajibkan menulis nama lengkap seperti pada surat pemerolehan warga negara sehingga harus mengganti ijasah, KTP,KK,SKCK, dan surat lainnya yang memang tidak menggunakan nama marganya. Peraturan Catatan Sipil mengharuskan hanya menggunakan nama aslinya sendiri. Hal tersebut menyebabkan sebagian WNA yang menjadi WNI menjadi malas untuk mengurus sendiri dan akhirnya menyerahkan kepada Makelar Surat. 
Berdasarkan catatan Komisi Pelayanan Publik lebih dari 80 kasus pengaduan telah dilayangkan masyarakat antara bulan Januari-April 2007. Banyaknya kasus-kasus pengaduan yang dimuat dalam Harian Nasional maupun yang dialamatkan kepada Komisi Pelayanan Publik (KPP) telah cukup memberikan gambaran betapa kualitas penyelenggaraaan pelayanan publik masih mengahadapi banyak persoalan.

Berbagai rekaman kasus-kasus di atas tergambar jelas bahwa Peraturan Daerah tentang Pelayanan Publik diintrepretasikan secara berbeda antara Pemerintah Pusat dengan Pemerintah Daerah, juga antara instansi pemerintah yang satu dengan lainnya. Terkait dengan itu semua, peneliti bermaksud melakukan penelitian terhadap para pejabat publik sebagai penyelenggara pelayanan untuk mengetahui; 1. Bagaimana interpretasi para pejabat publik di Kota Surabaya tentang Peraturan Daerah yang berkenaan dengan Pelayanan Publik ?2. Bagaimana pelaksanaan Peraturan Daerah Tentang Pelayanan Publik di Kota Surabaya ? 3. Adakah keterkaitan antara interpretasi para pejabat publik dengan pelaksanaan Peraturan Daerah Tentang Pelayanan Publik di Kota Surabaya?

\section{Pembahasan}

\section{Interpretasi Pejabat Publik Terhadap Perda Tentang Pelayanan Publik di Surabaya.}

Sehubungan dengan keluarnya Peraturan Daerah tentang Pelayanan Publik di Jawa Timur, tidak semua pejabat public memiliki interpretasi yang sama terhadap produk aturan tersebut. Berbeda-bedanya interpretasi terhadap aturan terbut, dipengaruhi banyak factor antara lain: 1. Perda tentang pelayanan publik ini relative masih baru, sehingga petunjuk teknis untuk dilaksanakan di tiap-tiap instansi belum ada. 2. Tiap-tiap instansi atau penyelenggara layanan memiliki bidang pelayanan dan kharakteristik yang berbeda sehingga interpretasi terhadap perda tersebut menjadi berbeda pula.

Di samping itu berbeda-bedanya interpretasi terhadap peraturan pelayanan publik tidak diikuti dengan petunjuk teknis yang jelas, sehingga antara peraturan 
yang turun di tiap-tiap penyelenggara pelayanan dapat diinterpretasikan secara berbeda oleh tiap-tiap pejabat publik yang bersangkutan. Kondisi yang demikian menyebabkan kualitas pelayanan publik menjadi tidak sesuai standart yang diharapkan, apalagi jika setiap penyelenggara pelayanan publik belum memiliki standart pelayanan minimal yang dipublikasikan kepada masyarakat.

Belum berubahnya perilaku di kalangan pejabat publik sebagaimana diamanatkan dalam Perda Tentang pelayanan Publik N0 11 tahun 2005 pasal 13 tentang Tata Perilaku Penyelenggara. Penyelenggara pelayanan public wajib memiliki perilaku sebagai kode etik dalam memberikan pelayanan public, sebagai berikut:Bertindak jujur, disiplin, proporsional dan professional; Bertindak adil dan tidak diskriminatif; Peduli, teliti dan cermat; Bersikap ramah dan bersahabat; Bersikap tegas, dan tidak memberikan pelayanan yang berbelit-beli; Bersikap mandiri dan dilarang menerima imbalan dalam bentuk apapun; Transparan dalam pelaksanaan dan mampu mengambil langkah-langkah yang kreatif dan inovatif; juga merupakan kendala tersendiri dalam menginterpretasikan dan mengimplementasikan peraturan tersebut.

Masih terbatasnya sumber daya manusia yang berkualitas yang memahami dengan benar peraturan daerah yang ada, sehingga interpretasi terhadap aturan yang ada diinterpretasikan sesuai dengan kebutuhan atau kepentingan pejabat publik dan aparaturnya.

Masih lemahnya sanksi yang diberikan terhadap para penyelenggara pelayanan publik yang melakukan pelanggaran terhadap kode etik tata perilaku dalam memberikan pelayanan kepada masyarakat, sehingga tidak menimbulkan efek jera bagi para pelaku pelanggaran. Bahkan tidak jarang atasan berusaha menutupi pelanggaran penyelenggara pelayanan, semata-mata untuk menutupi kredibilitas dari instansi yang dipimpinnya.

Paradigma lama yaitu paradigma pemerintahan yang masih belum mengalami perubahan mendasar; yaitu paradigma lama yang ditandai dengan perilaku aparatur Negara di lingkungan birokrasi yang masih menempatkan dirinya untuk dilayani bukannya untuk melayani(Mustopadijaja, 2003). Padahal pemerintah seharusnya melayani bukan dilayani. Dalam era demoratisasi dan 
otonomi daerah saai ini, seluruh perangkat birokrasi, perlu menyadari bahwa pelayanan berarti semangat pengabdian yang mengutamakan efisiensi dan keberhasilan bangsa dalam membangun, yang dimanifestasikan dalam perilaku "melayani, bukan dilayani", "mendorong, bukan menghambat", "mempermudah bukan mempersulit", "sederhana, bukan berbelit-belit" "terbuka untuk setiap orang, bukan hanya untuk segelintir orang”.

Namun, lahirnya Perda tentang Pelayanan publikdi Jawa Timur secara umum direspon secara positip oleh para pejabat public di Surabaya. Walaupun disadari bahwa masih ada beberapa staf atau oknum yang merasa tidak diuntungkan dengan adanya perda tersebut sehingga hal ini yang membuat implementasi Perda tentang pelayanan public ini masih menemui sejumlah kendala. Satu hal yang dapat dijadikan salah satu indikasi adalah masih belum dipenuhinya Standart pelayanan minimum yang harus disediakan oleh beberapa instansi penyedia pelayanan public untuk dipublikasikan kepada public di Surabaya.

Untuk pejabat public yang memiliki kewenangan dalam pengambilan keputusan yang lebih besar, respon positip cenderung mendominasi temuan data dalam penelitian Ini. Bahkan interpretasi dan respon yang positip ini ada yang langsung diikuti dengan adanya kebijakan teknis yang langsung dikeluarkan untuk menunjukkan bahwa instansi yang dipimpinnya dapat diidentifikasi sebagai instansi yang dapat mengimplementasikan Perda tentang pelayanan Publik tersebut. Polwiltabes Surabaya misalnya, keluarnya MOU dengan Komisi Pelayanan Publik (KPP) tentang maklumat tentang pelayanan public menunjukkan bahwa intansi Polwiltabes memiliki komitmen untuk mengimplementasi perda tersebut dan berusaha menunjukkan komitmennya itu kepada masyarakat Surabaya bahwa Instansi Polwiltabes berkomitmen untuk meningkatkan kualitas pelayanan public kepada masyarakat Surabaya.

Pemkot Surabaya, juga merespons secara positip adanya perda tentang pelayanan public tersebut. Menurut Soekamto Hadi (Sekretaris Pemkot Surabaya) adanya perda tersebut menunjukkan bahwa pemerintah punya komitmen untuk mencapai good governance pemerintahan yang bersih dan berwibawa sesuai 
dengan cita-cita reformasi dan demokrasi yang berkembang saat ini dengan berusaha meningkatkan kualitas pelayanan public.

Kepala Sub Bag Pelayanan Informasi Pemerintah Kota Surabaya (Dra. Sri Puri Suryandari M.Si) menyatakan bahwa Pemkot Surabaya merespon secara positip upaya untuk meningkatkan kualitas pelayanan public seperti yang sudah di-Perda-kan di Propinsi Jawa Timur.. "Untuk mengimplementasikan perda tersebut beberapa hal telah dilakukan pemerintah untuk memberikan pelayanan yang prima kepada masyarakat Surabaya. Pemkot Surabaya dalam hal ini terus berusaha untuk memberikan pelayanan yang terbaik bagi masyarakat"Misalnya; khusus pada HUT Surabaya tahun ini Pemkot memberikan dua layanan gratis. Yaitu pembuatan KTP gratis untuk Lansia dan Akta Kelahiran untuk Balita di Surabaya. Diharapkan masyarakat dapat memanfaatkan fasilitas yang disediakan Pemkot Surabaya, dan sebagai bentuk respon pemkot Surabaya dalam implementasi Perda tentang layanan Publik di Jawa Timur.

\section{Implementasi Perda Tentang Pelayanan Publik di Surabaya Dalam Perspektif}

\section{Penyelenggara Pelayanan Publik}

\subsection{Perda Pelayanan Publik belum optimal}

Peraturan Daerah (perda) pelayanan Publik yang diterapkan di Jawa Timur khususnya di Surabaya masih memerlukan banyak pembenahan. Secara garis besar ada tiga focus pendekatan pembenahan pelayanan public, yaitu pendekatan system, kelembagaan dan pendekatan sumber daya manusia (SDM). Demikian disampaikan Sekertaris Propinsi Jawa Timur Soekarwo dalam seminar Persepsi dan Akseptasi Masyarakat terhadap Pelayanan public di Jawa Timur. Menurutnya upaya perbaikan dan peningkatan kualitas pelayanan public tidak dapat dilakukan secara parsial, tetapi diperlukan pembenahan secara menyeluruh dan terintegrasi, sesuai dengan karakteristik dan kemampuan daerah. Hal itu sebagaimana tertuang dalam Undang-Undang Nomor 32 tahun 2004 tentang Pemerintahan Daerah yang memberikan kewenangan kepada propinsi untuk meyelenggarakan pelayanan umum. 
Di Jawa Timur seluruh jenis pelayanan masyarakat harus bertumpu pada satu atap atau LPSA (Lembaga Pelayanan Satu Atap). Dalam implementasinya, pelayanan masyarakat Jawa Timur berada di bawah naungan suatu kantor atau Dinas. "Saat ini masih ada tujuh Kabupaten atau kota yang sudah berbentuk Dinas termasuk Surabaya. Sisanya masih berbentuk kantor. Tujuh kabupaten atau kota itu adalah Ngawi, Malang, sidoarjo, Pasuruan, Lumajang dan Mojokerto. Ada sebagian instansi yang masih menjadi kewenangan pusat, seperti Perpajakan, Bea Cukai, Imigrasi dan lain-lain. Yang masih menjadi persoalan adalah apakah instansi yang masih dalam kewenangan pusat itu juga harus tunduk pada Peraturan Daerah?.

Berbagai implementasi Perda tentang layanan public di Surabaya dapat dilihat dari berbagai upaya yang ditempuh pihak-pihak penyedia layanan public seperti Samsat dengan peningkatan kualitas layanan dengan membuat program Drive Thrue, kantor pemerintahan seperti Pemkot dengan program Public Expose, demikian juga upaya-upaya peningkatan kualitas layanan yang diberikan instansi seperti kantor Kelurahan, kecamatan Rumah sakit, PDAM, PLN dan Telkom.

\section{Keterkaitan Antara Interpretasi dan implementasi Perda Tentang Pelayanan}

\section{Publik di Surabaya : Menuju Optimalisasi Pelayanan Publik}

Pertanggungjawaban public dan pelayanan public dari aparat birokrasi sebenarnya tidak hanya ditentukan oleh factor intern, seperti interpretasi dan implementasi pejabat publik terhadap aturan terkait, namun juga dipengaruhi oleh perilaku kepemimpinan birokrasi, rangsangan yang memadai, kejelasan tugas dan prosedur kerja, kejelasan peran dan perlengkapan sarana dan prasarana kerja, dan sejenisnya. Akan tetapi juga karena factor ekstern, yang antara lain berupa norma sosial dan system budaya, seperti persepsi, sikap, nilai-nilai organisasi dan sentiment masyarakat terhadap kinerja aparat birokrasi. Dengan demikian, masalah tanggung jawab public dan pelayanan aparat birokrasi sebenarnya bukan semata-mata masalah aparat birokrasi, akan tetapi masalah semua pihak yang 
terlibat dalam urusan pemerintahan, sehingga perlu perhatian dari setiap komponen penyelenggara Negara. Pemerintah, tentunya harus direspons oleh semua pihak, karena kebijakan tersebut telah memberikan ruang public yang positif, sehingga bias diketahui, sebarapa besar tingkat capaian kinerja instansi public untuk memberikan feedback-nya terhadap kondisi yang terjadi berupa daya respons yang cerdas agar terpelihara pelayanan public yang diharapkan dan optimal.

Di samping itu, upaya untuk senantiasa meningkatkan kualitas kehidupan sosial dan demokrasi di Indonesia sangat ditentukan oleh dinamika kemasyarakan, kenegaraan dan kebangsaan. Dinamika masyarakat yang sehat, kontruktif dan demokratis akan berdampak positip terhadap penyelenggaraan pemerintahan. Sebab pemerintah akan memperoleh legitimasi yang kuat dan meluas. Sehingga melalui interaksi yang demokratis dan berkesinambungan kehidupan tatanan sosial politik akan lebih terarah dan kondusif bagi implementasi program-program pembangunan.

Dalam bidang pelayanan public, proses transformasi menuju terciptanya pelayanan public yang transparan, fair, akuntable dan demokratis menjadi langkah maju dalam sejarah pemerintahan. Clean and good governance merupakan langkah strategis menuju terwujudnya kemakmuran yang berkeadilan, dan pemerintahan yang bersih dari Korupsi, Kolusi dan Nepotisme (KKN).

Dalam model new public service, pelayanan public berlandaskan pada teori demokrasi yang mengajarkan adanya egaliter dan persamaan hak di antara warga Negara. Dalam model ini kepentingan public dirumuskan sebagai hasil dialog yang emansipatoris dan partisipatoris dari berbagai nilai dan aspirasi yang berkembang dalam masyarakat. Kepentingan public bukan dibakukan oleh elite politik seperti yang terteuang dalam aturan-aturan. Birokrasi yang memberikan pelayanan public harus beroreientasi dan bertanggung jawab kepada masyarkat secara keseluruhan.

Peranan pemerintah adalah melakukan negosiasi dan menggali berbagai kepentingan dari warga Negara dan berbagai kelompok komunitas yang ada. Dalam model ini, birokrasi poublik bukan sekedar harus akuntable pada berbagai 
aturan hukum, tetapi juga hatus akuntable pada nilai-nilai yang ada dalam masyarakat, norma politik yang berlaku, standart professional, dan kepentingan warga Negara. Itulah serangkaian konsep pelayanan public yang ideal masa kini di era demokrasi.

Seperti dalam paradigma new public service bahwa pelayanan public harus responsive terhadap berbagai kepentingan dan nilai yang ada. Tugas pemerintah adalah melakukan negosiasi dan mengelaborasi berbagai kepentingan komunitas. Ini mengandung makna bahwa karakter dan nilai yang terkandung dalam pelayanan public harus berisi preferensi nilai-nilai yang ada dalam masyarakat. Karena masyarakat bersifat dinamis, maka karakter pelayanan public juga harus selalu berubah mengikuti perkembangan masyarakat.

Di samping itu, pelayanan public dalam model baru harus bersifat nondiskriminatif sebagaimana dasar teoritis yang digunakan, yakni teori demokrasi menjamin adanya persamaan di antara warga Negara, tanpa membeda-bedakan asal-asul warga Negara, kesukuan, ras, etnis, agama, dan latar belakang kepartaian. Ini berarti bahwa setiap warga Negara diperlakukan sama ketika berhadapan dengan birokrasi public untuk menerima pelayanan sepanjang syaratsyarat yang dibutuhkan terpenuhi. Hubungan yang terjalin antara birokrast public dengan warganegara, adalah hubungan impersonal sehingga terhindar dari sifat nepotisme dan primordialisme.

Kualitas pelayanan public merupakan hasil interaksi dari berbagai aspek, yakni system pelayanan, sumber daya manusia pemberi pelayanan, strategi, dan customer, seperti nampak pada gambar berikut:

\begin{tabular}{|ll|}
\hline - & Sistem pelayanan \\
- & Sumber Daya manusia pemberi \\
& layanan \\
- & Strategi \\
- & Customer
\end{tabular}$\longrightarrow$ Kualitas pelayanan


Hasil survey yang dilakukan terhadap 150 responden yang ada di Surabaya, dan wawancara terhadap beberapa pejabat publik di Surabaya secara umum bahwa kualitas pelayanan public mengalami perbaikan setelah diberlakukannya Otonomi Daerah. Namun senada dengan pemikiran Muhammad (2003) dilihat dari sisi efisiensi dan efektifitas, responsibilitas, kesamaan perlakuan (tidak diskriminatif) masih jauh dari yang diharapkan dan masih memiliki berbagai kelemahan yang disebabkan: 1.Kurang responsive, seperti yang terjadi di beberapa instansi seperti BPN, PLN, PDAM maupun Dinas 2. Kurang Inovatif, berbagai informasi yang seharusnya disampaikan kepada masyarakat, lambat atau bahkan tidak sampai kepada masyarakat. 3. Kurang accessible; Berbagai unit pelaksana pelayanan terletak jauh dari jangkauan masyarakat, sehingga menyulitkan bagi mereka yang memerlukan pelayanan tersebut. 4. Kurang koordinasi; Berbagai unit pelayanan yang terkait satu dengan yang lainnya sangat kurang berkoordinasi. Akibatnya, sering terjadi tumpang tindih ataupun pertentangan kebijakan antara satu instansi pelayanan dengan instansi pelayanan yang terkait. 5.Birokrastis; Pelayanan (khususnya pelayanan perijinan dan pelayanan hak kepemilikan atas tanah dan bangunan) pada umumnya dilakukan dengan melalui proses yang terdiri dari berbagai level, sehinga menyebabkan penyelesaian pelayanan yang terlalu lama. Akibatnya, berbagai masalah pelayanan memerlukan waktu yang lama untuk diselesaikan. 6.Kurang mendengar keluhan/saran/aspirasi masyarakat. Akibatnya, pelayanan dilaksanakan dengan apa adanya, tanpa ada perbaikan dari waktu ke waktu. 7.Inefisien; Berbagai persyaratan yang diperlukan (khususnya dalam pelayanan perijinan) seringkali tidak relevan dengan pelayanan yang diberikan.

Di samping itu, karakteristik pelayanan pemerintah sebagian besar masih bersifat monopoli sehingga tidak menghadapi permasalahan persaingan pasar sehingga menjadikan lemahnya perhatian pengelola pelayanan public akan penyediaan pelayanan yang berkualitas. Lebih buruk lagi kondisi ini menjadikan sebagian pengelola pelayanan memanfaatkan untuk mengambil keuntungan pribadi, cenderung mempersulit prosedur pelayanannya. 
Adanya slogan yang berkembang dalam masyarkat Kalau bisa dipersulit mengapa dipermudah? Turut memperburuk kualitas pelayanan penyelenggara pelayanan public dalam masyarakat. Akibatnya, citra buruk pada pengelolaan pelayanan public masih melekat sampai saat ini sehingga tidak ada kepercayaan masyarakat kepada pengelola pelayanan. Kenyataan ini merupakan tantangan yang harus segera diatasi terlebih pada era persaingan bebas pada saat ini. Profesionalitas dalam pengelolaan pelayanan public dan pengembalian kepercayaan masyarakat kepada pemerintah menjadi hal penting yang harus menjadi prioritas utama untuk diwujudkan.

\section{Kesimpulan}

Sehubungan dengan keluarnya Peraturan Daerah tentang Pelayanan Publik di Jawa Timur No 11 tahun 2005 dan permasalahan yang diteliti terkait dengan perda tersebut, hasil penelitian menunjukkan bahwa tidak semua pejabat public memiliki interpretasi yang sama terhadap produk aturan tersebut. Berbedabedanya interpretasi terhadap aturan tersebut, dipengaruhi banyak factor antara lain: Pertama, Perda tentang pelayanan publik ini relative masih baru, sehingga petunjuk teknis untuk dilaksanakan di tiap-tiap instansi belum ada. Kedua, tiaptiap instansi atau penyelenggara layanan memiliki bidang pelayanan dan kharakteristik yang berbeda sehingga interpretasi terhadap perda tersebut menjadi berbeda pula. Ketiga, tidak adanya acuan yang seragam dan jelas dalam menginterpretasikan aturan dari pemerintah. Keempat. Belum berubah sepenuhnya paradigma di kalangan aparat pemerintah yang harus 'memberikan pelayanan' bukan untuk 'dilayani'. Kondisi yang demikian menyebabkan kualitas pelayanan publik menjadi tidak sesuai standart yang diharapkan, apalagi jika setiap penyelenggara pelayanan publik belum memiliki standart pelayanan minimal yang dipublikasikan kepada masyarakat. Hal ini dapat dilihat dari masih banyaknya jumlah pengaduan dan keluhan, serta tingkat ketidapuasan masyarakat terhadap berbagai bidang pelayanan yang diselenggarakan oleh penyelenggara pelayanan. 
Namun dalam melaksanakan perda tersebut secara umum para pejabat publik menganggap bahwa Perda tentang pelayanan Publik dianggap sebagai bentuk komitmen pemerintah untuk meningkatkan kualitas pelayanan public untuk warga Surabaya. Walaupun disadari bahwa implementasi perda tersebut masih belum optimal karena beberapa hal antara lain: belum dipenuhinya standart pelayanan minimal oleh berbagai penyelenggara pelayanan public, keterbatasan kualitas dan kuantitas sumber daya manusia, dan belum didukung fasilitas pelayanan yang optimal. Di tambah lagi belum diimplementasikannya kode etik profesi bagi para penyelenggara pelayanan publik karena berbagai alasan seperti masih rendahnya gaji, tidak adanya reward bagi penyelenggara pelayanan publik yang baik, dan tidak adanya insentif bagi aparat yang telah menjalankan tugasnya dengan baik dan profesional. Semuanya merupakan kendala yang dihadapi pemerintah Kota Surabaya dalam mengimplementasikan Perda tentang Pelayanan Publik.

\section{DAFTAR PUSTAKA}

Ahimsa, Heddy.

Pluralitas dan Tindak Kekerasan Massal: Paradigma Sosial Budaya. Makalah disampaikan dalam seminar di Fakultas Sastra, Universitas Airlangga di Surabaya, 28 Juli 2001.

Agustono, Budi.

Politik Lokal dan Otonomi Daerah. Pelaksanaan Otonomi Daerah di Kabupaten Deli Serdang Sumatera Utara. Makalah disampaikan dalam "International Conference on Indonesia; Democracy and local Politics", Yogyakarta, 7-8 Januari 2003.

Bogdan, Robert dan Steven J. Taylor

1985, Pengantar Metode Penelitian Kualitatif. Usaha Surabaya. Dwitanto, Agus. 
2002, Reformasi tata pemerintahan dan otonomi Daerah. Pusat Studi Kependudukan dan Kebijakan UGM.

Ember, Carol R. dan Melvin Ember.

1980 “Konsep Kebudayaan” dalam T.O. Ihromi (ed), Pokok-Pokok Antropologi Budaya. PT Gramedia: Jakarta.

Firzan Syahroni.

Perda Pelayanan Publik, Mimpi Indah Pemprof dan DPRD Jatim (Rakyat Jadi Raja, Pejabat Jadi Pelayan). Artikel dalam Laporan Khusus Metro, Jawa Pos 18 Desember 2005.

Geertz, Clfford

1973 The interpretation of Cultures. Basic Books Inc: New York.

Kertzer, David I.

1988 Ritual, Politics and Power. Yale University Press: New Heaven and London.

Kresnayana, Yahya

Harus Berubah menjadi Organisasi Service, Artikel dalam Laporan Khusus Metro, Jawa Pos 18 Desember 2005.

M.Said Sutomo.

Bumerang Perda Pelayanan Publik, Artikel dalam Opini, Jawa Pos 27 Desember 2005.

Miles, Matthew B. dan Michael B. Heberman

1984. Qualitatif Data Analysis: A Source of New Methods. Sage

Publication, London.

Meleong, Lexy J.

1991. Metodologi Penelitian Kualitatif. Remaja Rosdakarya, bandung. Weber, Max

1978. Economy and society: On Outline of Interpretative Socielogy.

University of California Press London.

Spradly, James P.

1980. Participant Obeservation. Holts, Rinehart and Winston : USA. 